\title{
Assessing the Rate of Shoreline Changes of Rameswaram Island, Tamilnadu, India, using MATLAB Component Runtime Utility \& Digital Shoreline Analysis System
}

\author{
Glitson Francis Pereira, Gurugnanam B, Saroj.B.Choudhury, Santonu Goswami, Bairavi S
}

\begin{abstract}
The Present study highlights the changes in the coastal tract of Rameswaram island located between the geometric location, latitude $9^{\circ} 10^{\prime}$ to $9^{\circ} 20^{\prime} \mathrm{N}$ and the longitude $79^{\circ} 12^{\prime}$ to $79^{\circ} 30^{\prime}$ E. Using Geospatial Technology, Long-term changes have noticed from digitized shorelines taken from Landsat imageries and SOI toposheet for the years 1968, 1978, 1988, 1999, 2009 and 2018. Digital Shoreline Analysis System (DSAS) an extension provided by USGS for ArcGIS used to cast transects perpendicular from the baseline, towards the shorelines. High water Line (HTL) has taken as shoreline in this study. The distance between the shorelines has taken from the cast transects plotted from the baseline. For the rate of change calculation, MATLAB component runtime utility for ArcGIS has used. Based on the Linear Regression Rate (LRR) the shore has classified into High Erosion, Low Erosion, Stable and Low Accretion, High Accretion zones. The island has a shoreline length of $78.4 \mathrm{~km}$, and the studies found that $27.83 \mathrm{~km}$ (35.41\%) of shoreline is accreting nature, $37.90 \mathrm{~km}(48.21 \%)$ of shoreline is stable, and $12.86 \mathrm{~km}(16.36 \%)$ of shoreline tends to erode. During the field investigation identified that High amount of erosion occurred in the locations near Pamban, Tharavaithopu and Dhanushkodi. Also, Accretion identified over the locations Ayyanthopu, Natarajapuram and Arichumanai tip. Wind action is one of the physical parameters that induced the erosion in some location of this study area.
\end{abstract}

Keywords: EPR.LRR, DSAS, MATLAB, Erosion, Accretion

\section{INTRODUCTION}

The coastal region is unique on earth surface, where always occur long and short-term changes [1], Erosion and Accretion are the frequent changes that would happen on the coastal regions caused either by natural force or Manmade. [2]Abundance of resources in sea makes peoples settle in near coastal. As a result, artificial constructions also increase. The shoreline is an active coastal feature between the land and sea [3]. In the coastal erosional and depositional studies, the shoreline only can expose the changes in the coast.

Revised Manuscript Received on February 05, 2020.

* Correspondence Author

Glitson Francis Pereira*, Centre for Applied Geology, The Gandhigram Rural Institute - Deemed to be University, Dindigul, Tamil Nadu, India. Email: glitson.p@gmail.com.

Gurugnanam B, Centre for Applied Geology, The Gandhigram Rural Institute - Deemed to be University, Dindigul, Tamil Nadu, India. Email: gurugis4u@gmail.com.

Dr.Saroj.B.Choudhury, Scientist-NRSC. Email: sarojnrsa@gmail.com Santonu Goswami, Scientist- National Remote Sensing Centre. Email: santonu.isro@gmail.com

Bairavi S, Centre for Applied Geology, The Gandhigram Rural Institute Deemed to be University, Dindigul, Tamil Nadu, India. Email: bairuguru98@gmail.com.

(C) The Authors. Published by Blue Eyes Intelligence Engineering and Sciences Publication (BEIESP). This is an open access article under the CC BY-NC-ND license (http://creativecommons.org/licenses/by-nc-nd/4.0/)
The satellite imageries with false-colour composition help to identify and extract the shoreline [4]. Arc GIS Software used to delineate the shoreline. Shorelines extracted from Multi-year satellite imageries was the recent trend which helps to identify and assess the changes [5].

\section{A. Study Area}

The study area is in Rameswaram district, Tamilnadu and study aim to find the erosional and depositional changes of the study area (Fig-1) over a time of five decades (19682019). The region is located between a latitude of $9^{\circ} 09^{\prime}$ to $9^{\circ} 20^{\prime} \mathrm{N}$ and the longitude of $79^{\circ} 11^{\prime}$ to $79^{\circ} 31^{\prime} \mathrm{E}$. Northern side of the study area is pak bay shore, and the southern side is Gulf of Mannar. During 1964 a powerfull cyclone which hit over there and vanishes most of the livelihood of this region. The study area has one of the famous pilgrimage centre, the Rameswaram temple, where tourism has a significant role in the economy of this region. Peoples mainly depends on sea and sea resources. Hence the constructional activities become increased over the island for making transportation and tourism spots. The littoral current during the northeast monsoon alters the coastal region over the island[6].The study Highlights the coastal locations which are under High erosion, Low Erosion. High Accretion, Less Accretion and Stable.

\section{MATERIALS AND METHODS}

\section{A. Shoreline Extraction}

The study was done using ArcGIS software and the multidate satellite data. Baseline has taken from the Survey of India toposheets acquired in 1968. Accordingly, Landsat satellite data which freely available in USGS -Earth Explorer has taken for demarcating multiyear shorelines for the period 1978 - 2018. Geometric errors have rectified by register using Ground Control Points (GCP's) acquired on field. The list of data mentioned in (Table:1)

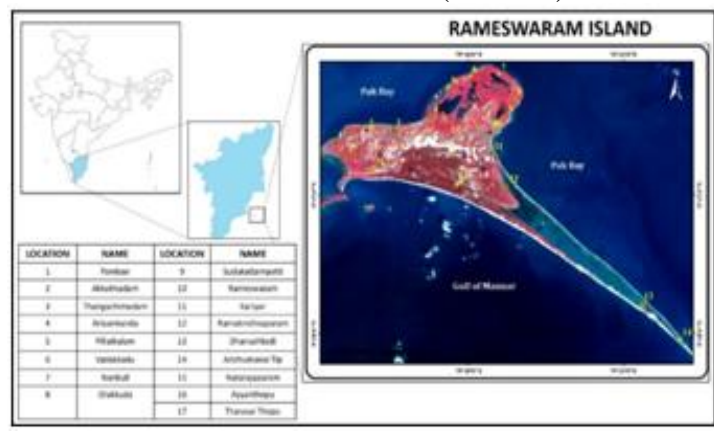

Fig - 1 Study Area

Published By: 


\section{B. Shoreline change analysis}

The shoreline change study was carried out by digitising the shorelines in the ArcGIS software. Digital Shoreline Analysis System (DSAS) is an extension tool that freely provided by USGS, works with ArcGIS platform[7].DSAS will operate to construct the transects from the baseline and this will used to calculate the horizontal movement of shoreline[8]. In the study area there are 697 transects with 100 -meter interval that constructed from the baseline is used for the Statistical calculation LRR and EPR has shown in (Fig-2). The MATLAB runtime monitor along with this DSAS which calculating the End Point Rate (EPR) by dividing the total distance between oldest and youngest shoreline by the total time and the Linear Square regression (LRR) has calculated by the position of shoreline on the transect with the time. The calculated output will give the rate of changes in meters. The Negative (-) values show rate of erosion and Positive $(+)$ values shows the rate of accretion. Based on the output the shoreline has classified as High Erosion, Low Erosion, High Accretion, Low Accretion and Stable listed in (Table:2).

Table: 1 List of spatial data products

\begin{tabular}{|l|l|l|}
\hline Sl. No & Data Products & $\begin{array}{l}\text { Year of } \\
\text { acquisition }\end{array}$ \\
\hline 1 & $\begin{array}{l}\text { SOI Toposheet } \\
(1: 50000)\end{array}$ & 1968 \\
\hline 2 & Landsat (MSS) & 1978 \\
\hline 3 & Landsat (MSS) & 1988 \\
\hline 4 & Landsat -7 & 1999 \\
\hline 5 & Landsat -7 & 2009 \\
\hline 6 & Landsat 8 OLI & 2018 \\
\hline
\end{tabular}

\section{RESULTS AND DISCUSSION}

\section{A. Identification of Erosion and Accretion of the study area}

Around the Rameswaram island has been occurring dynamic coastline changes over the period. There are various factors such as wind, Littoral wave and another anthropogenic parameter which influence in the coastline. The shoreline is $78.4 \mathrm{~km}$ length and the island is having $88.9 \mathrm{~km} 2$ area. The coastal region of the island which is mainly silt and sand deposits[9].The sandy seashores were exposed higher for the erosion, and accretion activities by wind and waves[10].,The Northern region of the island is Pak bay, and the southern region is Gulf of Mannar. The LRR and EPR for the five decades (1968-2018) have calculated for important island locations are given in (Table: 3 and Fig-4). The LRR values along Pillaikulam, Ariyankundu, Pamban, Dhanushkodi, Tharavai Thopu shows negative (-) values implies the erosion over that region. EPR for this region shows $>-3.39$ $\mathrm{m} / \mathrm{yr}$ that indicates relatively high erosion. The highest rate of erosion that occurs in pamban region where anthropogenic activities are more shown in (Fig-3) In the Island locations Ayyanthope, Natarajapuram, sudukattampatti, olakkuda, Karaiyur and arichumunai tip the LRR values are Positive (+) that indicates the shore fed with sediment deposition over the location and the EPR values comes up to $9.78 \mathrm{~m} / \mathrm{yr}$.The highest rate of accretion which occurs in arichumanai tip where the sandspit elongates toward the Sri Lankan coastal through the gulf of Mannar with an annual rate of $9.78 \mathrm{~m} / \mathrm{yr}$. The Graphical representation of the statistical values are given in (Fig- 5)

Table: 2 classifications based on EPR and LRR

\begin{tabular}{|l|l|l|}
\hline Sl. No & $\begin{array}{l}\text { Shoreline } \\
\text { classification }\end{array}$ & $\begin{array}{l}\text { EPR and } \\
\text { LRR } \\
\text { rate(m/yr.) }\end{array}$ \\
\hline 1 & High Erosion & $>-2$ \\
\hline 2 & Low Erosion & -1 to -2 \\
\hline 3 & Stable & -1 to 1 \\
\hline 4 & Low Accretion & 1 to 2 \\
\hline 5 & High Accretion & $>2$ \\
\hline
\end{tabular}
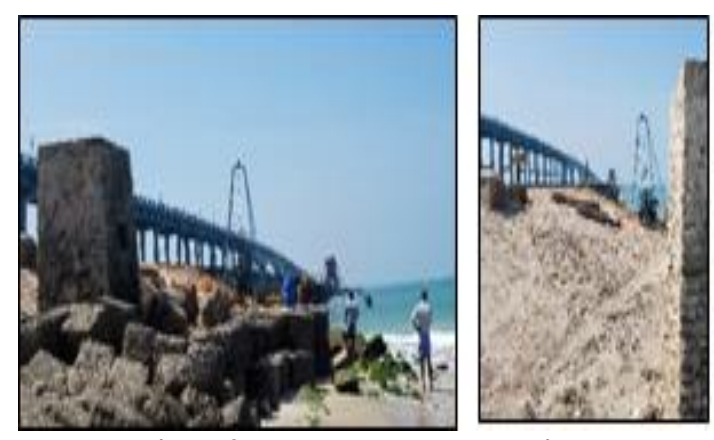

Fig - 2 Transet construction

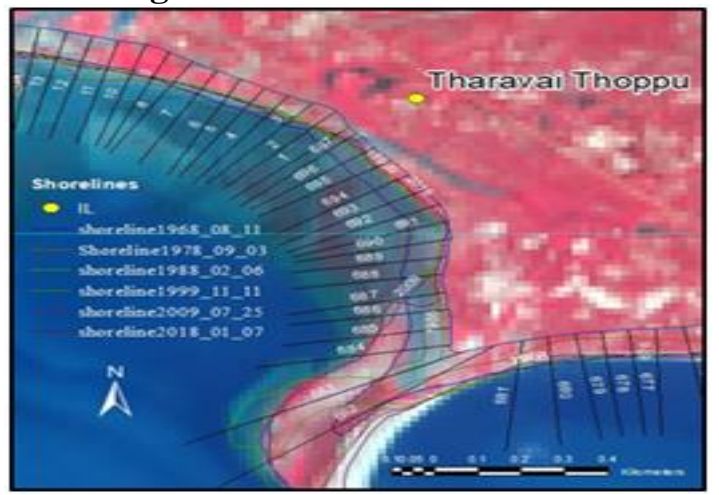

Fig - 3 Anthropogenic activities near Pamban Bridge
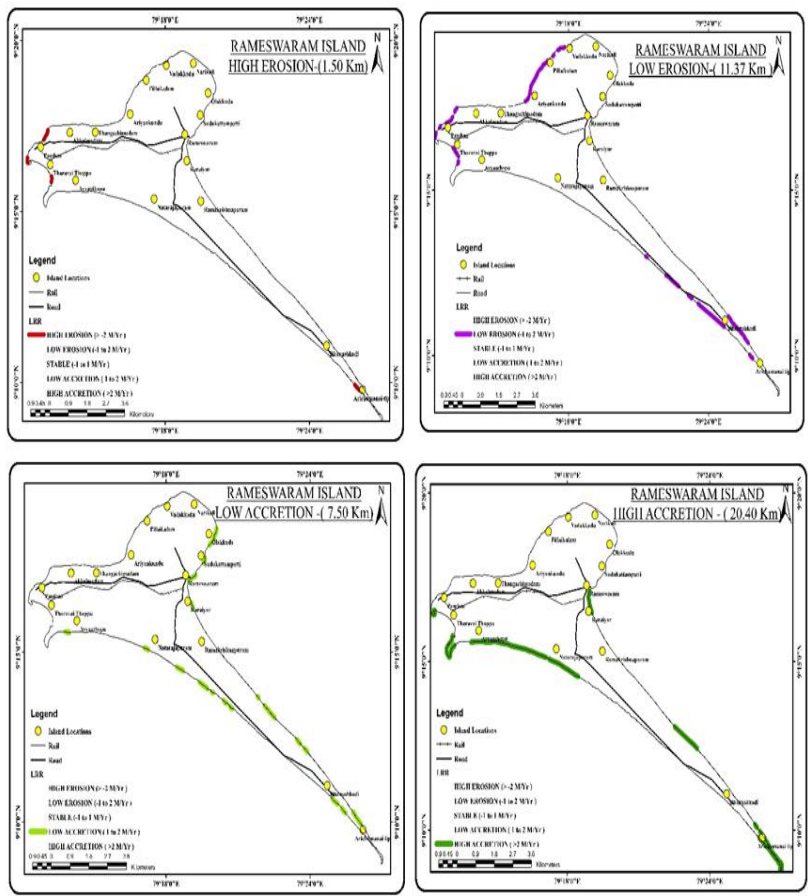

Fig - 4 shoreline classification based on End point Rate and Linear regression rate 


\section{CONCLUSION}

The coastal changes of the island have been predicted based on End Point rate and Linear Regression rate for Five decades (1968 - 2018) using the Digital Shoreline Analysis System. The study based on EPR and LRR have shown that erosion undertakes in the locations, Pillaikulam, Ariyankundu, Pamban, Dhanushkodi, Tharavai Thopu and Accretion mainly happens in Ayyanthope, Natarajapuram, sudukattampatti,olakkuda Karaiyur moreover in arichumunai Tip. The wind action over the region and Littoral current which influencing the morphological changes over the region. Human activities such as trenching and construction activities near the pamban bridge also making High erosional changes.

\section{ACKNOWLEDGEMENT}

The author acknowledges the Indian Space Research Organization (ISRO) -Respond Programme for the financial support of this research as well as the centre for Applied Geology of the Gandhigram Rural Institute (Deemed to be University).

Table :3 Statistical calculation of EPR and LRR

\begin{tabular}{|c|c|c|}
\hline Location & $\begin{array}{c}\text { EPR } \\
(\mathrm{m} / \mathrm{yr})\end{array}$ & LRR(m/yr) \\
\hline Pamban & -3.39 & -2.47 \\
\hline Akkalmadam & -0.98 & -0.37 \\
\hline Thangachimadam & -0.85 & -0.26 \\
\hline Ariyankundu & -2.88 & -2.89 \\
\hline Pillaikulam & -2.1 & -1.81 \\
\hline Vadakkadu & -0.15 & -0.06 \\
\hline Narikull & -0.41 & -0.59 \\
\hline Olakkuda & 2.34 & 2.74 \\
\hline
\end{tabular}

\begin{tabular}{|c|c|c|} 
sudukattampatti & 2.32 & 1.46 \\
\hline Rameswaram & 1.54 & 0.73 \\
\hline Kariyur & 2.84 & 3.01 \\
\hline Ramakrishnapuram & -0.66 & -0.89 \\
\hline Dhanushkodi & -1.17 & -0.68 \\
\hline Arichumanai Tip & 9.78 & 10.77 \\
\hline Natarajapuram & 4.13 & 3.96 \\
\hline Ayyanthopu & 4.99 & 4.96 \\
\hline Tharavai Thopu & -2.21 & -1.92 \\
\hline
\end{tabular}
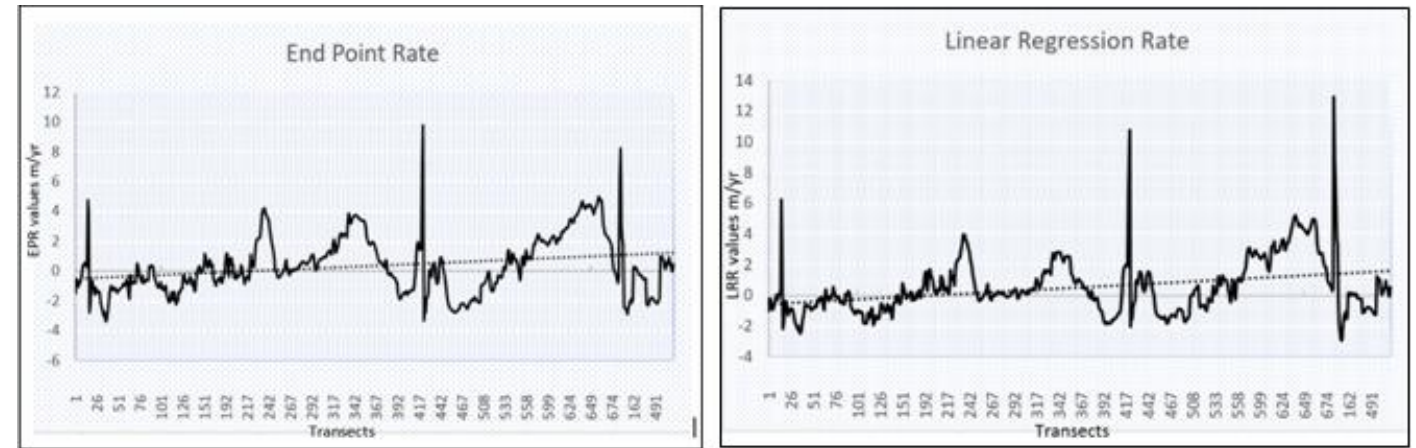

Fig -5. Graphical Representation of End point Rate and Linear regression rate of the study area

\section{REFERENCES}

1. Majed Bouchahma \& Wanglin Yan (2013) Monitoring shoreline change on Djerba Island using GIS and multi-temporal satellite data. Arab J Geosci (2014) 7:3705-3713

2. Usha Natesan, Anitha Parthasarathy, R. Vishnunath, G. Edwin Jeba Kumar and Vincent A. Ferrer.,2015. Monitoring long-term shoreline changes along Tamil Nadu, India using geospatial techniques, international conference on water resources, coastal and ocean engineering (icwrcoe 2015).

3. Anirban Mukhopadhyay1, Sandip Mukherjee, Samadrita Mukherjee, Subhajit Ghosh, Sugata Hazra1 and Debasish Mitra (2012) Automatic shoreline detection and future prediction: A case study on Puri Coast, Bay of Bengal, India, European Journal of Remote Sensing - 2012, 45: 201-213

4. Mageswaran T, Ram Mohan v. Chenthamil Selvan S, Arumugam T, Tune Usha, and Kankara R.S. Assessment of Shoreline changes along Nagapattinam Coast using Geospatial techniques, international journal of geomatics and geosciences volume 5, no 4, 2015

5. Lee J, Jurkevich I. (1990) - Coastline detection and tracing in SAR images. IEEE Transactions in Geosciences and Remote Sensing, 28: 662-668. International Journal of Engineering Science and Computing

6. Rajamanickam (2015) Nearshore waves and longshore sediment transport along Rameshwaram Island off the east coast of India. 7:939 950. International Journal of Naval Architecture and Ocean Engineering

7. G. Sreenivasulu (2016) River Mouth dynamics of Swarna Mukhi estuary, Nellore Coast, Southeast Coast of India, Geodesy Geodynamics. 1-9.

8. Sheeja P.S, Ajay Gokul A.J (2016) Application of Digital Shoreline Analysis System in Coastal Erosion. International Journal of Engineering Science and Computing, IJESC Volume 6 Issue No. 6
9. Glitson Francis Pereira (2018). Decadal Shoreline changes around Rameswaram island (1968-2018) using Remote sensing and GIS.in Eco-Chronicle, vol.13,pp.213-223

10. M. Rajamanickam, "Remote sensing and GIS application on beach placer minerals evaluation along the coast between Kallar and Vembar,” Ph.D., Thesis, Tamil University, Tanjore, pp.179 2006.

\section{AUTHORS PROFILE}

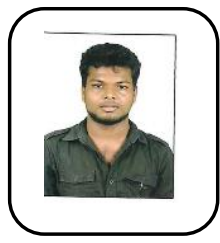

Glitson Francis Pereira, is a Ph.D., Scholar in Centre for Applied Geology, The Gandhigram Rural Institute - Deemed University. He did B.Sc., in Geology and M.Sc., in Applied Geology and Geomatics. Right now, He is doing Ph.D., in Remote sensing And GIS- Based Coastal Zone Morphological Studies In Rameswaram Coast Of Ramanathapuram District, East Coast Tamil Nadu, India

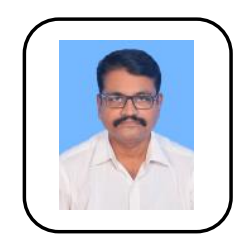

Dr.B.Gurugnanam, is a Professor of Geology in Center for Applied Geology, The Gandhigram Rural Institute - Deemed to be University. He has graduated in B.Sc., Geology and M.Sc., Applied Geology from Bharathidasan University. He did M.Phil., in Geology from University of Madras and M.Tech., in Remote sensing from Bharathidasan University. He did Ph.D., in Geospatial Technology application in water resources and specialised in Water, Disaster and Climate Change. He has 24 years of experience.

Published By:

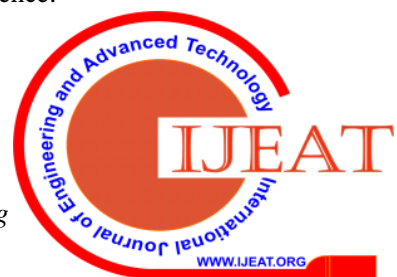


Assessing the Rate of Shoreline Changes of Rameswaram Island, Tamilnadu, India, using MATLAB Component Runtime Utility \& Digital Shoreline Analysis System

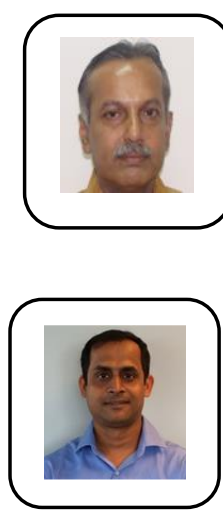

Dr.Saroj.B.Choudhury is Scientist, Head of Ocean Colour Division,OGS Group at National Remote Sensing Centre (ISRO),Department of Space,govt. Of India.

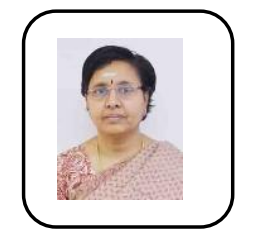

Santonu Goswami is Scientist at Indian Space Research Organization (ISRO) $\mathrm{He}$ ia an interdisciplinary environmental scientist, with a research focus on global change and its impact on ecosystem goods and services. His current research focuses in understanding the spatial \& temporal patterns of permafrost degradation and the associated changes in landscape evolution, hydrology, biogeochemical processes, and plant community succession from local to regional scale.

Bairavi S. is Guest Lecture in Center for Applied Geology, The Gandhigram Rural Institute - Deemed to be University. He has graduated in Mathematics from Bharathidasan university and Post Graduation in Geoinformatics from Annamalai University She did her Ph.D., in Geospatial Technology application in, Disaster management Studies 